\title{
ANALYSIS OF THE ORGANIC AGRICULTURE LEVEL OF DEVELOPMENT IN THE EUROPEAN UNION COUNTRIES
}

\author{
Bojan Krstić' ${ }^{1}$ Jelena Petrović ${ }^{2}$,Tanja Stanišic ${ }^{3}$, Ernad Kahrovic ${ }^{4}$
}

\begin{abstract}
Summary
The purpose of this paper is to analyse the development of organic agriculture in the member states of the European Union. The aim is ranking the member states of the European Union according to the degree of development of organic agriculture using the proper methodology, or using multi-criteria analysis, in order to determine which member state has made the most significant development of the observed agricultural production. This is realized by using the VIKOR and ENTROPY methods. The research results suggest that there is a difference in the level of development of organic agriculture in the member states of the European Union.Results of regression and correlation analysis indicate significant positive correlation between the levels of development of organic agricultural production and economic growth in the European Union countries. Economic growth is one of the conditions of improving the development of organic agriculture.
\end{abstract}

Keywords: Organic agriculture, multi-criteria analysis, economic growth

JEL: Q11,Q56, E23.

\section{Introduction}

In comparison with other sectors of a country's economy, agriculture as a whole is a complex system in which the economic principles of production are directly intertwined with its biological and ecological characteristics (Jaklic et al., 2014). The $21^{\text {st }}$ century is featured

1 Bojan Krstić Ph.D., Full Professor, University of Nis, Faculty of Economics, Trg Kralja Aleksandra no. 11, 18000, Nis, Serbia, Phone: +381 648096 208, E-mail: bojan.krstic@eknfak.ni.ac.rs

2 Jelena Petrović Ph.D., Associate Professor, University of Nis, Faculty of Mathematics and Science, Visegradska street no. 33, 18000, Nis, Serbia, Phone: +381 6311327 68, E-mail: jelena25@pmf.ni.ac.rs

3 Tanja Stanišić Ph.D., Assistant Professor, University of Kragujevac, Faculty of Hotel Management and Tourism in Vrnjačka Banja, Vojvodanska bb, 36210, Vrnjacka Banja, Serbia, Phone: +381 64 4941 542, E-mail: tanja.stanisic@gmail.com

4 Ernad Kahranović Ph.D., Assistant Professor, State University of Novi Pazar, Department of Economic Sciences, Vuka Karadzica bb, 36300, Novi Pazar, Serbia, Phone: +381 6529088 85, E-mail: ekahrovic@np.ac.rs

EP 2017 (64) 3 (957-971) 
by a dominant trend of the conventional agriculture representing "the industrial sector ofgrowing plants and breeding animals", which is based on the use of chemicals, machinery and genetically modified organisms. The contemporary form of the agriculture production is concentrated on reaching elevated of the output volumes, and reducing the overall hunger of the general population. However, this method of production causes economic, social as well as the environmental problems. The organic agriculture represents a solution that could eliminate such issues.

Agricultural production systems are facing a challenge. There is a rising demand for quality of agricultural products, which in turn will increase the pressure to further intensify agriculture systems, and,at the same time, there is a need to minimize its negative impacts on the environment (Ruschet al., 2015). In the recent years, a number of concepts have emerged that are related to the "environmentally-friendly" agricultural systems and among them the ones dealing with the organic agricultural system (Bruma, 2014). This concept should be viewed as an integral part of sustainable development strategies and as a viable alternative to conventional agriculture (Toader, Roman, 2014).“ All these challenges call for a more sustainable approach to agriculture, offering greater resilience to agriculture" (Te Pas, Rees, 2014).

The organic agriculture represents an ecologically clean, ethical and socially just agricultural production. It represents the integral part of the sustainable development because it employs renewable resources and avoids using mineral fertilizers, genetically modified organisms, pesticides, etc. in agriculture processes. In the long run, the modern agricultural production, and especially the organic production, can contribute to the increase of the soil quality and of biodiversity. Organic agriculture is based on the essential connection between the agriculture and nature, aiming tothe natural biological equilibrium. During the $20^{\text {th }}$ century, several European countries registered an increased presence of the organic agriculture (Germany, Switzerland, Austria, United Kingdom, France). A substantial development of the organic agriculture in the EU and in the rest of the world is due to the increased demand for the organic product and to the increased use of farmlands organic agriculture purposes. Organic agriculture has the potential to influence the protection of the environment and to contribute to the development of rural communities. The area of organic agricultureland, the number of organic produce farmers, and the market specializing in organic food continue to increase in the EU.

This research paper dedicates a particular attention to the analysis of factors related to the development of the organic agriculture on the EU territory, i.e. the EU member states. The main goals of this paper are: a) ranking observed countries in accordance with the level of development of the agricultural production, starting from the organic agriculture development factors; b) identifying the link between the value of the GDP (gross domestic product) and the level of development of the EU member states' organic agriculture. The analysis presented in this research paper points out the capabilities and the purposes of applying the VIKOR method asa the multi-criteria method in the research of the organic agriculture. 


\section{Literature review}

There are many definitions of the organic agriculture, but they are all based on the following principles: health, ecology, equality and sustainability. Accoording to the definition of the organic agriculture that was ratified in 2008 by the General Assembly of the International Federation of Organic Agriculture Movements (IFOAM), organic agriculture is a production system that sustains the health of soils, ecosystems and people (IFOAM, 2008). It relies on ecological processes, biodiversity and cycles adapted to local conditions, rather than the use of inputs with adverse effects. Organic agriculture combines tradition, innovation and science to benefit the shared environment and promote fair relationships and a good quality of life for all involved. Organic agriculture may be considered as a prototype for recycling agriculture (Nowak et al., 2015).

Organic agriculture is also known as the ecological agriculture (Gosling et al., 2006) or biodynamic agriculture (Lampkin, 2002). Some authors considered organic agriculture and sustainable agriculture synonymous, because they are both based on sustainability of agroecological systems. Despite some differences between the different schools of thought, the main aim of organic agriculture can be summarized as to create a sustainable agricultural production system. The term "sustainable" is used in a wide sense, in order to include the environmental, economic and social sustainability (Padel, 2001).

Organic agriculture uses an approach to growing crops and raising livestock that avoids using the synthetic chemicals, hormones, antibiotic agents, genetic engineering, and irradiation (Forman et al., 2012). Lampkin (1994) points out that the aim of organic agriculture is: "to create integrated, humane, environmentally and economically sustainable production systems, which maximize reliance on farm-derived renewable resources and the management of ecological and biological processes and interactions, so as to provide acceptable levels of crop, livestock and human nutrition, protection from pests and disease, and an appropriate return to the human and other resources."

Although worldwide organic agriculture is constantly gaining ground compared to traditional agriculture, anumber of countries have problems mostly related to the lack of validated information and knowledge, technical support byspecialized agronomists, coordination and organization of the trading network and promoting mechanisms (Karetsos et al., 2007). Globally, Europe continues to be a forerunner in organic agriculture. The positive development is due to a number of reasons, including strong consumer demand, legal protection and requirements for organic production and labelling as set out in the EU and national legislation, as well as the development of the private organic standards and labelling. The EU member states adopted organic standards, i.e. the standards that were officially adopted in the field of the organic agriculture by the International Federation of Organic Agriculture Movements (IFOAM). Some countries that did not adopt these regulations, are applying national standards in the field of agricultural production. Even though the national standards represent a point of reference for the certification systems and provide a definition for organic products, they usually do not foresee the adoption of a national inspection and certification system. 
Policies that encourage organic production should focus on attitudes, technology, and finances (Rozman et al., 2013). In addition, agricultural policy support measures (such as conversion and maintenance payments for organic production) have contributed positively to sectoral development (Sanders et al., 2011). In some countries, more coordinated policy approaches have also been promoted through national and regional organic action plans, which seek to link support measures with growth and expansion.

\section{Research methodology and hypothesis}

The information basis for this research is the Eurostat database, as well as data of the Research Institute of Organic Agriculture (FiBL) and the International Foundation for Organic Agriculture (IFOAM), that were presented in the publication ,The World of Organic Agriculture: Statistics and Emerging Trends 2016“ (FiBL, IFOAM, 2016).

In this paper, the authors hypothesized the following:

- Even though all the EU member states adopted the organic standards, there is an inequality in the organic agriculture development on the EU level, i.e. between the EU member states;

- The development of the organic agriculture in the EU member states depends on their economic development.

This research paper applies the following methods: the VIKOR method, the ENTROPY method, the correlation analysis method and the regression analysis method. The VIKOR method is used to rank the European Union countries according to the level of the organic agriculturedevelopment. The ENTROPY method is selected to determine the value of weight coefficients, as well as because it is an objective method - it generates the weights of criteria directly out of the criteria values of variables and eliminates the problem of subjectivity and incompetence, or of the lack of the decision maker. The correlation analysis method is used with the aim of determining interdependence between the level of the organic agriculture and the level of the economic growth, while the regression analysis is used in order to examine the effects of the economic growth on the level of development of the organic agriculture in the EU member states.

The VIKOR method was developed for multi-criteria optimization of complex systems and this method determines the compromise ranking list, the compromise solution, and the weight stability intervals for the preference stability of the compromise solution obtained with the initial (given) weights (Opricovic, Tzeng, 2004; Wang, Tzeng, 2012). The essence of the VIKOR method is related to finding the value $Q_{i}$ for each alternative, as well as to selecting the alternative that has the smallest value $Q_{i}$ (i.e. the smallest offset from the "ideal point"). The initial decision matrix represents the starting point in applying the VIKOR method of decision 


$$
\begin{aligned}
& \begin{array}{lll}
f_{1} & f_{2} & f_{3}
\end{array} \\
& \begin{array}{lll}
w_{1} & w_{2} & w_{3}
\end{array} \\
& \mathrm{R}=. A_{A_{n}}\left[\begin{array}{ccc}
f_{11} & \cdots & f_{1 m} \\
\vdots & \ddots & \vdots \\
f_{n 1} & \cdots & f_{n m}
\end{array}\right]
\end{aligned}
$$

Afterwards, the highest and the lowest values for $f_{j}^{*}$ and $f_{j}^{-}$respectively are determined for each criteria. The criteria that demands the minimum has the best point at its lowest value while the weakest point is the highest value. Based on the value $d_{i j}$ :

$$
d_{i j}=\frac{f_{j}^{*}-f_{i j}}{f_{j}^{*}-f_{j}^{-}}
$$

and the weight criteria one can determine the pessimistic solution $S_{i}$ and the expected solution $R_{i}$ by applying the following formulas:

$$
\begin{aligned}
& S_{i}=\sum_{j=1}^{n} w_{j} \frac{f_{j}^{*}-f_{i j}}{f_{j}^{*}-f_{j}^{-}}=\sum_{j=1}^{n} w_{j} d_{i j}, i=1,2, \ldots \ldots, m \\
& R_{i}=\max _{j} w_{j} d_{i j}, \quad i=1,2, \ldots \ldots, m
\end{aligned}
$$

These variables, in turn determine the variables $S^{*}$ and $S^{-}$and $R^{*}$ and defined as:

$$
\begin{aligned}
S^{*}=\min _{i} S_{i}, & R^{*}=\min _{i} R_{i} \\
S^{-}=\max _{i} S_{i}, & R^{-}=\max _{i} R_{i}
\end{aligned}
$$

On the basis of the variables $S^{*}, S^{-}, R^{*}$ and $R^{-}$one can calculate the variables $Q S_{i}, Q R_{i}$ and $Q_{i}$ (a compromise solution) for each alternative.

$$
\begin{gathered}
Q S_{i}=\frac{S_{i}-S^{*}}{S^{-}-S^{*}} \\
Q R_{i}=\frac{R_{i}-R^{*}}{R^{-}-R^{*}} \\
Q_{i}=v \cdot Q S_{i}+(1-v) \cdot Q R_{i}
\end{gathered}
$$

The variable $Q_{i}$ unifies the variables $Q S_{i}$ and $Q R_{i}$ (third ranking list). By selecting the value for $v$ (weight of satisfaction for most of criteria) the influence of the variable $Q S_{i}$ or $Q R_{i}$ can be favoured in the compromise ranking list $Q_{i}$ (Nikolic et al., 2010). The variable $v$ which represents the weight of criteria of maximizing the group landmark or "the maximum group usefulness" may have the following values 0,25 ; 0,50 or 0,75 (Opricovic, Tzeng, 2007).

Ranking the alternatives is carried out by sorting the values on the ranking list QS, QR and EP 2017 (64) 3 (957-971) 
$Q_{i}$ in a descending order. The alternative $\mathrm{A}_{i}$ that has the lowest value on the ranking list $Q_{i}$ $(v=0,5)$ is the best alternative provided that the following conditions have been met:

Condition U1 - condition of ,sufficient advantage”

$$
Q\left(A_{2}\right)-Q\left(A_{1}\right) \geq D Q
$$

Where $\mathrm{A}_{2}$ represents the alternative that occupies the second position on the ranking list $Q_{i}(\mathrm{v}=0,5)$, and amounts to: $D Q=\frac{1}{m-1}$.

The condition U2 is the condition of the "acceptable sustainability in decision-making".

The alternative $\mathrm{A}_{1}$ except on the raking list $Q_{i}(\mathrm{v}=0,5)$ has to be the best ranked one, that is to have the lowest value on at least one of the following raking lists $\mathrm{QS}, \mathrm{QR}, Q_{i}(\mathrm{v}=0,25)$ and $Q_{i}(\mathrm{v}=0,75)$. If $\mathrm{A}_{1}$ does not satisfy the aforementioned conditions, then the compromising solution contains:

1) The alternatives $A_{1}$ and $A_{2}$ if the condition $U 2$ hasn't been satisfied;

2) The alternatives $A_{1}, A_{2}, \ldots A_{m}$ if the condition $U 1$ hasn't been satisfied, where $\mathrm{A}_{\mathrm{m}}$ was determined by the relation $Q\left(A_{m}\right)-Q\left(A_{\nu}\right)<D Q$ for the maximum $m$ (Opricović, Tzeng, 2007).

The multi-criterion decision-making is related to situations where there is an elevated number of mostly conflicting criteria. In order to make a good decision, it is necessary to specify the alternatives by defining the adequate criteria. The weight coefficients represent the numbers that can be calculated by applying the objective and subjective methods (CRITIC method, the least squares method, AHP method, ENTROPY method, etc.) (Alemi-Ardakani et al., 2016; Solsvik, Jakobsen, 2012; Hazama, Kano, 2015; Yu et al., 2015).

In this research paper, the authors apply ENTROPY method as an objective method to determine the value of the weight coefficients. The ENTROPY method was originally a concept of thermodynamics, which firstly added into the information theory by C.E. Shannon and it is not applied widely in the field of engineering technology, social economy, etc. (Zhang, 2015).

Beginning from the initial decision matrix, we can determine the weight criteria in the following three steps. In the first step the normalization of criteria values of $a_{i j}$ variants is carried out, in the following way:

$$
r_{i j}=\frac{a_{i j}}{\sum_{i=1}^{n} a_{i j}}
$$

By applying the above model, we can obtain a normalized decision matrix: 


$$
\begin{gathered}
c_{1} \\
\mathrm{R}=A_{i} \\
A_{1} \\
\vdots \\
A_{m}
\end{gathered}\left[\begin{array}{cccccc}
r_{11} & \cdots & c_{j} & \cdots & \multicolumn{2}{c}{c_{n}} \\
\vdots & \ddots & \vdots & \ddots & \vdots \\
r_{i 1} & \cdots & r_{i j} & \cdots & r_{i n} \\
\vdots & \ddots & \vdots & \ddots & \vdots \\
r_{m 1} & \cdots & r_{m j} & \cdots & r_{m n}
\end{array}\right]
$$

In the second step, the entropy value $\mathrm{e}_{\mathrm{j}}$ is calculated by applying the following model:

$$
e_{j}=-k \sum_{i=1}^{n} r_{i j} \ln r_{i j}
$$

The constant value $k$ which is calculated in the following way allows for all the entropy values to be in-between the interval. In the second step we determine the degree of divergence in relations to the average quantity of information that is contained in each criterion:

$$
d_{j}=1-e_{j}
$$

whererepresents the characteristic contrast intensity of the criterion .

In the third step, the final weight of the criterion is obtained by doing a simple additive normalization:

$$
w_{j}=\frac{d_{j}}{\sum_{j=1}^{m} d_{j}}
$$

\section{Research results and discussion}

During the determination of weight criteria, we start from the initial decision matrix which is formed based on key indicators of organic agriculture for the EU-28 member states (Table 1). In order to rank the EU-28 member states, we used the following as the key indicators of the development of the organic agriculture: area (ha), area share (\%), producers, and processors.

Based on the data from the Table 1, and by applying the models 7, 9, 10 and 11 we determine the values of the coefficients weight . Based on the value of the weight criteria for each criterion of each alternative and by applying the VIKOR method, we carried out the ranking of the EU-28 member states according to the level of development of the organic agriculture (Table 2). 
Table 1. Key indicators of development of the organic agriculture in the EU-28 member states in 2014 and average GDP growth rate from 2000 to 2014

\begin{tabular}{|c|c|c|c|c|c|}
\hline Country & $\begin{array}{c}\text { Area } \\
\text { (ha) }\end{array}$ & $\begin{array}{c}\text { Area share } \\
(\%)\end{array}$ & Producers & Processors & $\begin{array}{c}\text { GDP growth } \\
\text { (annual \%) } \\
2000-2014 \\
\end{array}$ \\
\hline Austria $\left(\mathrm{A}_{1}\right)$ & 525521 & 19.4 & 22184 & 2118 & 1.39076 \\
\hline Belgium $\left(\mathrm{A}_{2}\right)$ & 66704 & 4.9 & 1648 & 844 & 1.29216 \\
\hline Denmark $\left(\mathrm{A}_{3}\right)$ & 165773 & 6.3 & 2565 & 787 & 0.57541 \\
\hline Finland $\left(\mathrm{A}_{4}\right)$ & 212653 & 9.4 & 4247 & 648 & 1.18587 \\
\hline France $\left(\mathrm{A}_{5}\right)$ & 1118845 & 4.1 & 26466 & 11198 & 1.08577 \\
\hline Germany $\left(A_{6}\right)$ & 1047633 & 6.3 & 23398 & 9497 & 1.04542 \\
\hline Greece $\left(\mathrm{A}_{7}\right)$ & 256131 & 3.1 & 20186 & 1635 & -0.12597 \\
\hline Ireland $\left(\mathrm{A}_{8}\right)$ & 51871 & 1.3 & 1275 & 197 & 2.28549 \\
\hline Italy $\left(\mathrm{A}_{0}\right)$ & 1387913 & 10.8 & 48662 & 12641 & -0.28815 \\
\hline Luxembourg $\left(\mathrm{A}_{10}\right)$ & 4490 & 3.4 & 79 & 72 & 2.38730 \\
\hline Netherlands $\left(\mathrm{A}_{11}\right)$ & 49159 & 2.5 & 1706 & 1138 & 0.98598 \\
\hline Portugal $\left(\mathrm{A}_{12}\right)$ & 212346 & 6.3 & 3029 & 437 & 0.04889 \\
\hline Spain $\left(A_{13}\right)$ & 1710475 & 6.9 & 30602 & 3082 & 1.39234 \\
\hline Sweden $\left(\mathrm{A}_{14}\right)$ & 501831 & 16.4 & 5406 & 855 & 1.92575 \\
\hline $\begin{array}{l}\text { United Kingdom } \\
\left(\mathrm{A}_{15}\right)\end{array}$ & 521475 & 3 & 3526 & 2487 & 1.69930 \\
\hline Bulgaria $\left(\mathrm{A}_{16}\right)$ & 74351 & 2.4 & 3893 & 132 & 3.24647 \\
\hline Croatia $\left(A_{17}\right)$ & 50054 & 3.8 & 2194 & 242 & 1.47393 \\
\hline Cyprus $\left(\mathrm{A}_{18}\right)$ & 3887 & 2.7 & 743 & 51 & 1.41277 \\
\hline $\begin{array}{ll}\text { Czech } & \text { Republic } \\
\left(\mathrm{A}_{10}\right) & \\
\end{array}$ & 472663 & 11.1 & 3866 & 506 & 2.43375 \\
\hline Estonia $\left(\mathrm{A}_{20}\right)$ & 155560 & 16.2 & 1542 & 109 & 3.57362 \\
\hline Hungary $\left(\mathrm{A}_{21}\right)$ & 124841 & 2.7 & 1672 & 257 & 1.82258 \\
\hline Latvia $\left(\mathrm{A}_{20}\right)$ & 203443 & 11.2 & 3497 & 63 & 4.03087 \\
\hline Lithuania $\left(\mathrm{A}_{23}\right)$ & 164390 & 5.7 & 2445 & 67 & 4.35150 \\
\hline Malta $\left(\mathrm{A}_{24}\right)$ & 34 & 0.3 & 10 & 9 & 1.65720 \\
\hline Poland $\left(\mathrm{A}_{25}\right)$ & 657902 & 4.3 & 24829 & 484 & 3.56607 \\
\hline $\operatorname{Romania}\left(\mathrm{A}_{26}\right)$ & 289252 & 2.1 & 14159 & 120 & 3.65236 \\
\hline Slovakia $\left(\mathrm{A}_{27}\right)$ & 180307 & 9.5 & 403 & 56 & 4.02968 \\
\hline Slovenia $\left(\mathrm{A}_{28}\right)$ & 41237 & 8.9 & 3293 & 236 & 1.85629 \\
\hline
\end{tabular}

Source: FIBL; IFOAM, https://shop.fibl.org/fileadmin/documents/shop/1698-organicworld-2016.pdf; Eurostat, http://appsso.eurostat.ec.europa.eu/nui/show.do?dataset=org lstspec\&lang=en; IFOAM, http://www.ifoam-eu.org/en/austria

According to the obtained variables QS, QR and $\mathrm{Q}_{i}$ for each of the EU-28 member states, we can form three independent ranking lists. According to all the criteria, QS, $\mathrm{QR}$ and $\mathrm{Q}_{\mathrm{i}}(\mathrm{v}=0,5)$ the best alternative is $\mathrm{A}_{9}$ (Italy). 
Table 2. Ranking lists based on the variables $\mathrm{QS}, \mathrm{QR}$ and $\mathrm{Q}_{\mathrm{i}}(\mathrm{v}=0.5 ; 0.25 ; 0.75)$

\begin{tabular}{|c|c|c|c|c|c|c|}
\hline Country & QS & QR & $Q_{i}(v=0.5)$ & $Q_{i}(v=0.25)$ & $Q_{i}(v=0.75)$ & Rang \\
\hline Austria $\left(\mathrm{A}_{1}\right)$ & 0.61415 & 0.81418 & 0.71417 & 0.76418 & 0.61415 & 5 \\
\hline $\operatorname{Belgium}\left(\mathrm{A}_{2}\right)$ & 0.92588 & 0.92643 & 0.92615 & 0.92629 & 0.92588 & 15 \\
\hline Denmark $\left(\mathrm{A}_{3}\right)$ & 0.90078 & 0.93145 & 0.91611 & 0.92378 & 0.90078 & 13 \\
\hline Finland $\left(\mathrm{A}_{4}\right)$ & 0.87241 & 0.94370 & 0.90805 & 0.92588 & 0.87241 & 11 \\
\hline France $\left(\mathrm{A}_{5}\right)$ & 0.25862 & 0.20971 & 0.23416 & 0.22194 & 0.25862 & 2 \\
\hline Germany $\left(A_{6}\right)$ & 0.33657 & 0.25431 & 0.29544 & 0.27488 & 0.33657 & 3 \\
\hline Greece $\left(\mathrm{A}_{7}\right)$ & 0.76963 & 0.85674 & 0.81318 & 0.83496 & 0.76963 & 7 \\
\hline Ireland $\left(\mathrm{A}_{8}\right)$ & 0.97290 & 0.98344 & 0.97817 & 0.98080 & 0.97290 & 25 \\
\hline Italy $\left(\mathrm{A}_{q}\right)$ & 0.00000 & 0.00000 & 0.00000 & 0.00000 & 0.00000 & 1 \\
\hline $\begin{array}{l}\text { Luxembourg } \\
\left(\mathrm{A}_{10}\right)\end{array}$ & 0.98001 & 0.99445 & 0.98723 & 0.99084 & 0.98001 & 26 \\
\hline $\begin{array}{l}\text { Netherlands } \\
\left(\mathrm{A}_{11}\right)\end{array}$ & 0.93034 & 0.90053 & 0.91543 & 0.90798 & 0.93034 & 12 \\
\hline Portugal $\left(\mathrm{A}_{12}\right)$ & 0.90397 & 0.96229 & 0.93313 & 0.94771 & 0.90397 & 16 \\
\hline Spain $\left(A_{13}\right)$ & \begin{tabular}{l|}
0.42699 \\
\end{tabular} & 0.72925 & 0.57812 & 0.65368 & 0.42699 & 4 \\
\hline Sweden $\left(\mathrm{A}_{14}\right)$ & 0.77904 & 0.92546 & 0.85225 & 0.88886 & 0.77904 & 9 \\
\hline 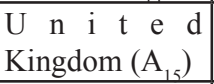 & 0.80061 & 0.78167 & 0.79114 & 0.78641 & 0.80061 & 6 \\
\hline Bulgaria $\left(\mathrm{A}_{16}\right)$ & 0.95054 & 0.98916 & 0.96985 & 0.97951 & 0.95054 & 24 \\
\hline Croatia $\left(\mathrm{A}_{17}\right)$ & 0.95263 & 0.97947 & 0.96605 & 0.97276 & 0.95263 & 23 \\
\hline Cyprus $\left(\mathrm{A}_{18}\right)$ & 0.98067 & 0.99630 & 0.98848 & 0.99239 & 0.98067 & 27 \\
\hline $\begin{array}{l}\text { Czech Republic } \\
\left(\mathrm{A}_{19}\right)\end{array}$ & 0.83346 & 0.95621 & 0.89483 & 0.92552 & 0.83346 & 10 \\
\hline Estonia $\left(\mathrm{A}_{20}\right)$ & 0.87955 & 0.99119 & 0.93537 & 0.96328 & 0.87955 & 17 \\
\hline Hungary $\left(\mathrm{A}_{21}\right)$ & 0.95041 & 0.97815 & 0.96428 & 0.97121 & 0.95041 & 22 \\
\hline Latvia $\left(\mathrm{A}_{22}\right)$ & 0.88961 & 0.99524 & 0.94242 & 0.96883 & 0.88961 & 18 \\
\hline Lithuania $\left(\mathrm{A}_{23}\right)$ & 0.93088 & 0.99489 & 0.96288 & 0.97889 & 0.93088 & 21 \\
\hline Malta $\left(\mathrm{A}_{24}\right)$ & 1.00000 & 1.00000 & 1.00000 & 1.00000 & 1.00000 & 28 \\
\hline Poland $\left(\mathrm{A}_{25}\right)$ & 0.71958 & 0.95815 & 0.83886 & 0.89851 & 0.71958 & 8 \\
\hline Romania $\left(\mathrm{A}_{26}\right)$ & 0.86076 & 0.99022 & 0.92549 & 0.95785 & 0.86076 & 14 \\
\hline Slovakia $\left(\mathrm{A}_{27}\right)$ & 0.92072 & 0.99586 & 0.95829 & 0.97707 & 0.92072 & 20 \\
\hline Slovenia $\left(\mathrm{A}_{28}\right)$ & 0.92015 & 0.98000 & 0.95008 & 0.96504 & 0.92015 & 19 \\
\hline
\end{tabular}

Source: Authors' calculation

During the first step, we examine if the alternative $\mathrm{A}_{9}$ satisfy the condition U1, which it does, since:

$$
\begin{gathered}
\mathrm{Q}_{5}-\mathrm{Q}_{9}=0,23416-0,00000=0,23416 \\
\mathrm{DQ}=\min (0.25 ; 1 /(28-1))=0,037 \\
\mathrm{Q}_{9}-\mathrm{Q}_{5}>\mathrm{DQ} .
\end{gathered}
$$

At the same time, the alternative $\mathrm{A}_{9}$ satisfies also the condition $\mathrm{U} 2$ because it covers the first place on all ranking lists.Given that it satisfies both conditions we can conclude that Italy has achieved a greater level of development of the organic agriculture compared to France. 
In the second step, we conduct the analysis of the alternative $\mathrm{A}_{5}$, the second on the ranking list $Q_{i}(v=0,5)$. At first, we test the condition $\mathrm{U} 1$ in the following way:

$$
\mathrm{Q}_{6}-\mathrm{Q}_{5}=0,29544-0,23416>0,037 \text {. }
$$

The first condition is satisfied, because the second alternative $\mathrm{A}_{5}$ has "sufficient advantage" in relations to the third alternative of the ranking list, $\mathrm{A}_{6}$. The condition U2 has been satisfied successfully because the alternative has a sufficiently stable second place, according to all the criteria $\mathrm{QS}, \mathrm{QR}$ and $\mathrm{Q}_{\mathrm{i}}(\mathrm{v}=0,5 ; 0,25 ; 0,75)$.

During the third step, we conduct the analysis of the alternative $\mathrm{A}_{6}$, the third one on the ranking list $Q_{i}(v=0,5)$. At first, we test the condition $\mathrm{U} 1$ in this way:

$$
\mathrm{Q}_{13}-\mathrm{Q}_{6}=0,57812-0,29544>0,037 \text {. }
$$

The first condition is satisfied, because the third alternative $\mathrm{A}_{6}$ has the "sufficient advantage" over the fourth alternative on the ranking list $\mathrm{A}_{13}$. Therefore, the top level of development of the organic agriculture has been achieved by Italy, the second place is held by France and the third place is held by Germany. Malta is on the twenty-eighth place, because it achieved the lowest level of development of organic agriculture on the EU-28 territory. Based on this, it can be concluded that the first research hypothesis has been confirmed. That is to say, there is an inequality of development of the organic agriculture between the EU-28 member states.

Table 3. Correlation between the development of the organic agriculture and the economic growth of the EU-28 member states

\begin{tabular}{|l|l|l|l|}
\hline & & \multicolumn{1}{|c|}{$\begin{array}{c}\boldsymbol{Q}_{\boldsymbol{i}} \\
(\boldsymbol{v}=\mathbf{0 . 5})\end{array}$} & \multicolumn{1}{|c|}{$\begin{array}{c}\text { GDP growth } \\
\text { (annual \%) } \\
\mathbf{2 0 0 0 - 2 0 1 4}\end{array}$} \\
\hline \multirow{3}{*}{$Q_{i}(v=0.5)$} & Pearson Correlation & 1 & $0.445^{*}$ \\
\cline { 2 - 4 } & Sig. (2-tailed) & & 0.018 \\
\cline { 2 - 4 } & $\mathrm{N}$ & 28 & 28 \\
\hline & & & \\
\hline
\end{tabular}

*Correlation is significant at the 0.05 level (2-tailed).

Source: Authors' calculation (SPSS Statistics 22)

For the purposes of examining the interdependence between the level of development of the organic agriculture and the level of economic growth in the EU member states, table 3 presents the calculation of the value of the Pearson's correlation coefficient between the annual growth rates of the GDP during the time period 2000-2014 and the level of development of the organic agriculture which is confirmed by the variable $Q_{i}$ $(v=0.5)$.

Based on the value Sig. (2-tailed), we can conclude that there is a statistically significant correlation between the organic agriculture and the economic growth of the EU-28 member states, because the observed value is less than 0.05 . The correlation coefficient value of 0.445 points out to the positive interdependency. 
The results of the correlation analysis from the Table 3 indicate the need of observing the influence of the level of the economic growth in the EU member states on the development of the organic agricultural production output (Table 4).

Table 4. The economic growth influence on the organic agriculture development in the EU-28 member states

\begin{tabular}{|l|r|r|r|r|}
\hline \multicolumn{6}{|c|}{ Model Summary $^{\mathbf{b}}$} \\
\hline Model & R & R Square & Adjusted R Square & $\begin{array}{c}\text { Std. Error of the } \\
\text { Estimate }\end{array}$ \\
\hline 1 & $0.445^{\text {a }}$ & 0.198 & 0.167 & 0.22846839 \\
\hline & & & & \\
\hline
\end{tabular}

a. Predictors: (Constant), GDP growth (annual \%) 2000-2014

b. Dependent Variable: Qi ( $=0.5)$

Source: Authors' calculation (SPSS Statistics 22)

The coefficient of determination indicates what part of the variance of the dependent variable explains the model. The coefficient of determination equals to 0.198 . When converted into percentages, we can conclude that the influence of the average growth rate of the GDP on the development of the organic agricultural output amounts to $19.8 \%$, i.e. the development change of the organic agriculture of $19.8 \%$ is conditioned by the average growth rate of the GDP. While the influence of other factors that have not been considered by this model amounts to $80.2 \%$. In the table 5, we can observe the contribution of the economic growth in the EU member states to the organic agricultureby using the regression analysis method.

Table 5. The contribution of the economic growth in the EU-28 member states to the organic agriculture

\begin{tabular}{|c|c|c|c|c|c|c|}
\hline & \multirow{2}{*}{$\begin{array}{c}\text { Model } \\
\text { B }\end{array}$} & \multicolumn{2}{|c|}{$\begin{array}{c}\text { Unstandardized } \\
\text { Coefficients }\end{array}$} & \multirow[t]{2}{*}{$\begin{array}{c}\text { Standardized } \\
\text { Coefficients }\end{array}$} & \multirow[b]{2}{*}{$\mathbf{t}$} & \multirow{2}{*}{ Sig. } \\
\hline & & $\begin{array}{l}\text { Std. } \\
\text { Error }\end{array}$ & Beta & & & \\
\hline \multirow[b]{2}{*}{1} & (Constant) & 0.659 & 0.079 & & 8.348 & 0.000 \\
\hline & $\begin{array}{l}\text { GDP growth (annual \%) } \\
\text { 2000-2014 }\end{array}$ & 0.087 & 0.034 & 0.445 & 2.531 & 0.018 \\
\hline & & & & & & \\
\hline
\end{tabular}

Dependent Variable: Qi $(\mathrm{v}=0.5)$

Source: Authors' calculation (SPSS Statistics 22)

When the Sig. value is lower than 0.05 , the variable gives a significant contribution to the prediction of the dependent variable. When this variable is greater than 0.05 , it can be concluded that the variable does not give a significant contribution to the prediction of the dependable variable. Based on the results by the regression method, we can conclude that the observed factor has a significant influence on the development of the organic agriculture in the EU. In this way, the second initial research hypothesis is EP 2017 (64) 3 (957-971) 
confirmed. The contribution of the economic growth to the development of the organic agriculture in the EU can be expressed by a linear regression formula: . The variable $\mathrm{b}_{1}=0.087$ indicates that the change of the average growth rate of the GDP of $1 \%$ shall condition the change of the organic agriculture for the $0.087 \%$.

\section{Conclusion}

The modern agricultural production based on using the machinery, chemical and other specialized technologies, represents the conventional agricultural production. The increase of the agricultural production intensity as the result of applying the chemical technologies has had a negative impact on the environment quality and on food. Therefore, while confronting the issue of providing a sufficient quantity of food without the negative impact on the quality of the environment, states found the solution in the new way of growing plants and breeding animals called the organic agriculture.

The results of applying the VIKOR method pointed out that the highest level of development of the organic agriculture was reached by Italy, France and Germany. These three countries have been designated as the "countries of good practices", i.e. the countries whose development model of the organic agriculture should be adopted by the other EU countries. According to the results of the VIKOR method, the EU countries with the modest accomplishments in the field of agriculture production, i.e. the countries that hold the last places on the presented list are Ireland, Luksemburg, Cyprus and Malta. The task of governmentsof these countries, but also the task of the creator of the common agricultural policy at the European Union level in the following period should be to increase the effort towards promoting and creating the conditions for an intensive organic agriculture, by using the development models from the "countries of good practices".

This paper examined the economic growth rate as one of the possible causes of the relative lag of countries in developing the organic agriculture. The results of the correlation analysis have indicated that there is a positive (the correlation coefficient value of 0.445 ) and a statistically significant (Sig. 0.018) correlation link between the economic growth and the development of the organic agriculture in the observed states. The regression analysis pointed out that a $19.8 \%$ of change in the development of the organic agriculture output can be explained by the economic growth of the EU-28 member states and that there is a significant positive influence of the economic growth on the level of development of the organic agriculture (the regression coefficient value of 0.087 ). In that regard, the economic growth is one of the conditions that can contribute to a more proficient development of the organic agriculture.

\section{References}

1. Alemi-Ardakani, M., Milani, A. S., Yannacopoulos, S., Shokouhi, G. (2016): On the effect of subjective, objective and combinative weighting in multiple criteria decision making: A case study on impact optimization of composites, Expert Systems with Applications, Vol. 46, No. 15, pp. 426-438, Elsevier, London, 
United Kingdom.

2. Bruma, I. S. (2014): The Evolution Of Organic Agricultural Land Areas In The Emerging Countries Of The European Union, Agricultural Economics and Rural Development, Vol. 11, No. 2, pp. 167-179, Premier Publisher, Birmingham, United Kingdom.

3. FIBL, IFOAM (2016): The world of organic agriculture: statistics \& emerging trends 2016, Switzerland (available at: https://shop.fibl.org/fileadmin/documents/shop/1698-organic-world-2016.pdf)

4. Forman, J., Silverstein, J. (2012): Organic foods: health and environmental advantages and disadvantages, Pediatrics, Vol. 130, No. 5, pp. 1406-1415, American Academy of Pediatrics, Chicago, USA.

5. Gosling, P., Hodge, A., Goodlass, G., Bending, G. D. (2006): Arbuscularmycorrhizal fungi and organic farming. Agriculture, Ecosystems \& Environment, Vol. 113, No. 1, pp. 17-35, Elsevier, London, United Kingdom.

6. Hazama, K., Kano, M. (2015): Covariance-based locally weighted partial least squares for high-performance adaptive modeling, Chemometrics and Intelligent Laboratory Systems, No. 146, pp. 55-62, Elsevier BV, Amsterdam, Netherlands.

7. IFOAM (available at: http://www.ifoam-eu.org/en/austria)

8. IFOAM (2008): Definition of Organic Agriculture, Switzerland (available at: http://www.ifoam.bio/en/organic-landmarks/definition-organic-agriculture)

9. Jaklic, T., Juvancic, L., Kavcic, S., Debeljak, M. (2014): Complementarity of socio-economic and emergy evaluation of agricultural production systems: The case of Slovenian dairy sector, Ecological Economics, No. 107, pp. 469481, Elsevier BV, Amsterdam, Netherlands.

10. Kaminski, M., Ossowski, N. (2014): Stokes problems with random coefficients by the Weighted Least Squares Technique Stochastic Finite Volume Method, Archive of civil and mechanical engineering, Vol. 14, No. 4, pp. 745-756, Elsevier BV, Amsterdam, Netherlands.

11. Karetsos, S., Costopoulou, C., Sideridis, A., Patrikakis, C., Koukouli, M. (2007): Bio@gro-an online multilingual organic agriculture e-services platform, Information Services \& Use, Vol. 27, No. 3, pp. 123-132, IOS Press, Amsterdam, Netherlands.

12. Lampkin, N. (2002): Organic Farming, Old Pond Publishing, Ipswich, England.

13. Lampkin, N. (1994): Organic farming: sustainable agriculture in practice, in Lampkin, N., Padel, S. (Eds.), The Economics of Organic Farming, An International Perspective, CABI, Oxford, United Kingdom.

14. Nikolić, M., Radovanović, L., Desnica, E., Pekez, J. (2010): Primena metode VIKOR za izbor strategije održavanja, Tehnička dijagnostika, Vol. 9, No. 4, pp. 25-32, Tehnička dijagnostika, Beograd, Srbija.

15. Nowak, B., Nesme, T., David, C., Pellerin, S. (2015): Nutrient recycling in 
organic farming is related to diversity in farm types at the local level, Agriculture, Ecosystems \& Environment, No. 204, pp. 17-26, Elsevier, London, United Kingdom..

16. Opricovic, S., Tzeng, G. (2007): Extended VIKOR method in comparison with outranking methods, European Journal of Operational Research, Vol. 178, No. 2, pp. 514-529, Elsevier BV, Amsterdam, Netherlands.

17. Opricovic, S., Tzeng, G. (2004): Compromise solution by MCDM methods: $A$ comparative analysis of VIKOR and TOPSIS, European Journal of Operational Research, Vol. 156, No. 2, pp. 445-455, Elviser VB, Amsterdam, Netherlands.

18. Padel, S. (2001): Conversion to organic farming: a typical example of the diffusion of an innovation?, Sociologia Ruralis, Vol. 41, No. 1, pp. 40-61, Blackwell Publishing Ltd., Oxford, United Kingdom.

19. Rozman, Č., Pažek, K., Kljajić, M., Bavec, M., Turk, J., Bavec, F., Kofjan, D., Škraba, A. (2013): The dynamic simulation of organic farming development scenarios - A case study in Slovenia, Computers and electronics in agriculture, No. 96, pp. 163-172, Elviser VB, Amsterdam, Netherlands.

20. Rusch, A., Delbac, L., Muneret, L., Thiéry, D. (2015): Organic farming and host density affect parasitism rates of tortricid moths in vineyards, Agriculture, Ecosystems \& Environment, No. 214, pp. 46-53, Elsevier, London, United Kingdom.

21. Sanders, J.,Stolze, M., Padel, S. (2011): Use and efficiency of public support measures addressing organic farming, Thunen-Institute of Farm Economics, Braunschweig, Germany.

22. Solsvik, S., Jakobsen, H. A. (2012): Effects of Jacobi polynomials on the numerical solution of the pellet equationusing the orthogonal collocation. Galerkin, tau and least squares methods, Computers and Chemical Engineering, Vol. 39, No. 6, pp. 1-21, Pergamon, Oxford, United Kingdom.

23. Te Pas, C. M., Rees, R. M. (2014): Analysis of differences in productivity, profitability and soil fertility between organic and conventional cropping systems in the tropics and sub-tropics, Journal of Integrative Agriculture, Vol. 13, No. 10, pp. 2299-2310, Elviser VB, Amsterdam, Netherlands.

24. Toader, M., Roman, GH.V. (2014): Manual de agricultură general, Editura Terra Nostra, Iaşi.

25. Wang, Y. L., Tzeng, G. H. (2012): Brand marketing for creating brand value based on a MCDM model combining DEMATEL with ANP and VIKOR methods, Expert Systems with Applications, Vol. 39, No. 5, pp. 5600-5615, Pergamon, Oxford, United Kingdom.

26. Yu, W., Li, B., Yang, X., Wang, Q. (2015): A development of a rating method and weighting system for green store buildings in China, Renewable Energy, No. 73, pp. 123-129, Pergamon, Oxford, United Kingdom.

27. Zhang, H. (2015): Application on the Entropy method for determination of 
weight of evaluating index in fuzzy mathematics for wine quality assessment, Advance Journal of Food Science and Technology, Vol. 7, No. 3, pp. 195-198, Institute of Food Science \& Technology, London, United Kingdom.

\title{
ANALIZA RAZVOJA ORGANSKE POLJOPRIVREDNE PROIZVODNJE U ZEMLJAMA EVROPSKE UNIJE
}

\author{
Bojan Krstic ${ }^{5}$, Jelena Petrović ${ }^{6}$, Tanja Stanišićc ${ }^{7}$ Ernad Kahrović ${ }^{8}$
}

\begin{abstract}
Rezime
Svrha ovog rada je da istraži faktore razvoja organske poljoprivredne proizvodnje u državama članicama Evropske unije. Cilj rada je da se odgovarajućom metodologijom, odnosno primenom višekriterijumske analize izvrši rangiranje država članica Evropske unije prema stepenu razvoja organske poljoprivredne proizvodnje da bi se utvrdilo koja država članica je ostvarila najznačajniji razvoj posmatrane proizvodnje. Istraživanje se realizuje primenom VIKOR $i$ ENTROPY metode. Rezultati istraživanja su pokazali da članice Evopske unije beleže različiti nivo razvoja organske poljoprivrede. Rezultati regresione $i$ korelacione analize su ukazali na to da postoji značajna pozitivna korelaciona veza nivoa razvoja organske poljoprivredne proizvodnje i privrednog rasta u članicama Evropske unije. Privredni rast predstavlja jedan od faktora unapređenja razvoja organske poljoprivredne proizvodnje.
\end{abstract}

Ključne reči: organska poljoprivreda, višekriterijumska analiza, privredni rast.

5 Redovni professor, dr Bojan Krstić, Univerzitet u Nišu, Ekonomski fakultet,Trg KraljaAleksandra br. 11, 18000, Niš, Srbija, Telefon: +381 648096 208, E-mail: bojan.krstic@eknfak.ni.ac.rs

6 Vanredni professor, dr Jelena Petrović, Univerzitet u Nišu, Prirodno-matematički fakultet, Visegradska ulica br. 33, 18000, Niš, Srbija, Telefon: +381 6311327 68, E-mail: jelena25@pmf.ni.ac.rs

7 Docent, dr Tanja Stanišić, Univerzitet u Kragujevcu, Fakultet za hotelijerstvo i turizam u Vrnjačkoj Banji, Vojvodanska ulica bb, 36210 Vrnjačka Banja, Srbija, Telefon: +381 644941 542, E-mail: tanja.stanisic@gmail.com

8 Docent, dr Ernad Kahranović, Državni univerzitet u Novom Pazaru, Departman za ekonomske nauke, Ulica Vuka Karadžica bb, 36300 Novi Pazar, Srbija, Telefon: +381 65290 88 85, E-mail: ekahrovic@np.ac.rs

EP 2017 (64) 3 (957-971) 